\title{
Residual Effect of Manure and Fertilizer on Growth, Yield of Chickpea and Soil Nutrient Status under Maize-Chickpea Cropping System
}

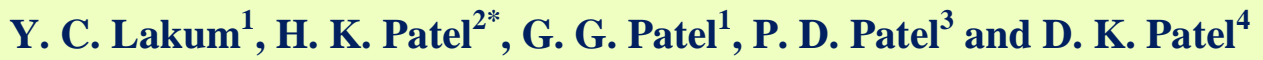 \\ ${ }^{1}$ Krushi Vigyan Kendra, Devataj, India \\ ${ }^{2}$ AICRP on Forage Research, ICAR Unit-9, India \\ ${ }^{4}$ Department of Agronomy, BACA Anand Agricultural University, Anand, Gujarat, India \\ *Corresponding author
}

\section{A B S T R A C T}

\begin{tabular}{|l|}
\hline Ke y w o r d s \\
Agronomy farm, \\
$\begin{array}{l}\text { Direct and residual } \\
\text { effect }\end{array}$ \\
\hline Article Info \\
\hline $\begin{array}{l}\text { Accepted: } \\
\text { 22 March } 2020 \\
\text { Available Online: } \\
\text { 10 April 2020 }\end{array}$ \\
\hline
\end{tabular}

\begin{abstract}
A field experiment was conducted at the Agronomy Farm, B. A. College of Agriculture, Anand Agricultural University, Anand during two consecutive Kharif and rabi seasons of the year 2015-16 and 2016-17 with a view to study the "Direct and residual effect of organic manures and inorganic fertilizers on maize (Zea mays L.)- chickpea (Cicer arietinum L.) cropping sequence". The experiment comprised of four levels of organic manures viz., $\operatorname{Control}\left(\mathrm{M}_{1}\right), \operatorname{FYM}\left(\mathrm{M}_{2}\right)$, castor cake $\left(\mathrm{M}_{3}\right)$, vermicompost $\left(\mathrm{M}_{4}\right)$; and two levels of Recommended dose of fertilizers $\left(100 \%\left(\mathrm{~F}_{1}\right)\right.$ and $75 \%\left(F_{2}\right)$ of RDF) and two levels of sulphur $\left(0\left(S_{1}\right)\right.$ and $\left.20\left(S_{2}\right) \mathrm{kg} \mathrm{S} / \mathrm{ha}\right)$. The experimental plots were laid out in Randomized Block design with four replications. The kharif maize was fertilized as per different treatment combinations and its residual effect was study on rabi chickpea. The results revealed that growth, yield attributes, seed and stover yields of chickpea and available $\mathrm{N}$ and $\mathrm{P}_{2} \mathrm{O}_{5}$ status were significantly increased due to different organic manurial treatments $\left(\mathrm{M}_{2}, \mathrm{M}_{3}\right.$ and $\left.\mathrm{M}_{4}\right)$ over control $\left(\mathrm{M}_{1}\right)$ and highest seed yield was recorded by residual effect of FYM @ $10 \mathrm{t} / \mathrm{ha}\left(\mathrm{M}_{2}\right)$ and being at par with vermicompost $\left(\mathrm{M}_{3}\right)$, castor cake $\left(\mathrm{M}_{4}\right)$. The residual effects of $100 \%$ RDF was significantly affected on seed \& stover yields and available $\mathrm{N}$ over $75 \% \mathrm{RDF}$ while in case of sulphur treatments, non-significant results were observed in all cases except weight of nodules/plant. Hence, in maizechickpea cropping sequence, application of 100\% RDF (120-60-0 kg NPK/ha) and FYM @ 10t/ha to maize crop gave better residual effect on crop yields of succeeding crop chickpea.
\end{abstract}

\section{Introduction}

Pulses are considered as an important food crop occupying a unique position in agriculture and also an important component of food grain crops because of their high nutritive value. Pulses also have inherent capacity to fix atmospheric nitrogen and adaptability to a wide range of agro- ecological, cropping system and management ability. Amongst the grain legumes, chickpea occupies third position in crop productivity.

Maize-Chickpea is one of the most prevalent cropping system in some part of Gujarat. In continuous cropping, use of imbalanced nutrients (NP or $\mathrm{N}$ alone) through inorganic fertilizers without organic manure cannot 
sustain the desired level of crop production. Indian soils are poor in organic carbon due to less buildup of organic carbon in tropical climate. Sulphur is considered as fourth major nutrient in crop growth and development and reports indicated that more than 30 per cent soils of Gujarat and India deficient in available sulphur. Integration of inorganic fertilizer with organic manures will sustain the crop production and also effective in improving soil health and enhancing the nutrient use efficiency. Looking to the importance of role of organic manure along with chemical fertilizers in crop production and maintaining soil health, the investigation planned on prominent cropping sequence like maize-chickpea with certain objectives.

\section{Materials and Methods}

The field experiment entitled, "Direct and residual effect of organic manures and inorganic fertilizers on maize (Zea mays L.) chickpea (Cicer arietinum L.) cropping sequence" was carried out during kharif and rabi seasons of the years 2015-16 and 201617 at College Farm, Department of Agronomy, B.A. College of Agriculture, Anand Agricultural University, Anand. The texture of the soil is loamy sand. The soil is very deep and fairly moisture retentive. It is suitable for variety of crops of tropical and sub-tropical regions. The soil of experimental site had low organic carbon $(0.45 \%)$, low available $\mathrm{N}(250.88 \mathrm{~kg} / \mathrm{ha})$, medium available $\mathrm{P}_{2} \mathrm{O}_{5}(48.54 \mathrm{~kg} / \mathrm{ha})$ and $\mathrm{SO}_{4}-\mathrm{S}(15.24 \mathrm{mg} / \mathrm{kg})$; and high available $\mathrm{K}_{2} \mathrm{O}(315.84 \mathrm{~kg} / \mathrm{ha})$. There were total four levels of organic manure like $\left(\mathrm{M}_{1}\right.$ : no manure, $\mathrm{M}_{2}$ : FYM 10 t/ha, $\mathrm{M}_{3}$ : castor cake $1.0 \mathrm{t} / \mathrm{ha}$ and $\mathrm{M}_{4}$ : vermicompost $2.5 \mathrm{t} / \mathrm{ha}$ ); two levels of inorganic fertilizer $\left(\mathrm{F}_{1}: 75 \%\right.$ $\mathrm{RDF}$ and $\mathrm{F}_{2}: 100 \% \mathrm{RDF}$ ) and two sulphur levels $\left(S_{1}: 0 \mathrm{~kg} \mathrm{~S} / \mathrm{ha}\right.$ and $\left.\mathrm{S}_{2}: 20 \mathrm{~kg} \mathrm{~S} / \mathrm{ha}\right)$. The experimental design was Randomized Block Design (Factorial) with four replications. Recommended dose of fertilizer (120-60-0 $\mathrm{kg} / \mathrm{ha}$ ) was applied by urea and DAP chemical fertilizer and sulphur was applied in form of Gypsum to maize crop and residual effect was study on chickpea crop var. GG 2 (Gujarat Gram 2). All agronomical practices and plant protection measure was followed for better and successful crop production. The chickpea seeds were treated bio-fertilizer (Rhizobium thiogangnaticum) before sowing. The observation on growth and yield attributes were recorded by randomly selected five plants from net plot area and tagged all plants for further observations. The data of various parameters were statistically analyzed using analysis of variance (ANOVA) technique and the treatments were compared at $5 \%$ levels of significance (Cochran and Cox, 1967).

\section{Results and Discussion}

\section{Effect of organic manures}

Organic fertilizers are natural materials of either plant or animal source, including livestock manure, green manures, crop residues, household waste, compost, and works directly as a source of plant nutrients and indirectly influences the physical, chemical and biological properties of soil. Microorganisms from the soil decay the organic fertilizers to make its nutrients available for utilize by plants which added into the soil and have the characteristic nature of the slow release of nutrients

Data presented in Table 1 indicated that plant population at 20 DAS was non-significantly affected by residual effect of organic manures and almost uniform plant population was observed in all experimental plots. The number of nodules/plant (21.8) and nodules weight $(225.20 \mathrm{mg} / \mathrm{plant})$ was observed significantly highest under previously applied of FYM@10 t/ha $\left(\mathrm{M}_{2}\right)$ to maize crop over control $\left(\mathrm{M}_{1}\right)$ and castor cake $\left(\mathrm{M}_{3}\right)$ but being at par with vermicompost $\left(\mathrm{M}_{4}\right)$. The increased in 
the nodules/plant and nodule weight/plant due to residual effect of organic manure treatment over control might be attributed to the built up of residual soil fertility and increase in the microbial population in root zone after addition of organic manures for continuous two seasons. Sindhi et al., (2016) also reported the similar findings.

The seed index, seed and stover yields of chickpea were significantly increased due to residual effect of $10 \mathrm{t} \mathrm{FYM} / \mathrm{ha}\left(\mathrm{M}_{2}\right)$ over control $\left(\mathrm{M}_{1}\right)$ whereas being at par with castorcake $\left(\mathrm{M}_{3}\right)$ and vermicompost $\left(\mathrm{M}_{4}\right)$. The treatment $\mathrm{M}_{2}$ recorded significantly highest seed index $(26.1 \mathrm{~g})$, seed yield $(1199 \mathrm{~kg} / \mathrm{ha})$ and stover yield (1794 kg/ha).

The increased in seed yield of chickpea due to residual effect of FYM, castor cake and vermicompost manures over control was to the tune of 28.0, 20.2 and 24.0 percent, respectively. It might be ascertained to the increased in availability of nutrients, release of $\mathrm{CO}_{2}$ increasing fertilizer use efficiency, accumulation of organic carbon and improvement of soil physical properties also.

The residual effect of organic manure increased in chickpea seed yield might be due to improvement in soil physical, chemical and biological properties and also serves as a source of energy for soil microflora which resulted in better root nodulation and nitrogen fixation (De Datta and Hundal, 1984).

The persistent material in organic manures requires more time for its decomposition, hence, about 25 to $33 \%$ of nitrogen and small fraction of phosphorus and potassium in organic manure may be available to immediate crop i.e. maize and rest to subsequent crops (Inoko, 1984) which sustain the productivity. Utilization of inexhaustible atmospheric nitrogen through biological nitrogen fixation can helps a great deal in maintaining soil productivity. These results are in confirmation with those reported by Gawai and Pawar (2006). The protein content in chickpea was significantly influenced by residual effect of organic manure treatments applied to preceding maize and especially the treatment $\mathrm{M}_{2}$ which recorded significantly highest protein content $(21.3 \%)$ (Table 1$)$.

The improvement in protein content in seed might be due to increase in nitrogen content in seed. Application of organic manures helped in more efficient translocation of $\mathrm{N}$ from vegetative parts to develop seed as well as in the synthesis of protein from the reduced nitrogen compounds within seeds as coenzyme pyridoxyl phosphate or pyridoxamine phosphate involved in the transmission reaction and activation of amino acids for protein synthesis in the presence of enzyme and ATP. These results are in accordance with those of Shahid et al., (2017).

The available $\mathrm{N}, \quad \mathrm{P}_{2} \mathrm{O}_{5}$ and $\mathrm{S}$ were significantly improved by residual effect of organic manures treatments over control whereas available $\mathrm{K}_{2} \mathrm{O}$ was non-significantly altered in soil after harvest of chickpea. The significantly highest available $\mathrm{N}$ (291.5 $\mathrm{kg} / \mathrm{ha}), \mathrm{P}_{2} \mathrm{O}_{5}(63.8 \mathrm{~kg} / \mathrm{ha})$ and $\mathrm{S}(18.0 \mathrm{mg} / \mathrm{kg})$ was recorded with the treatment $\mathrm{M}_{4}$ (Vermicompost 2.5t/ha) and being at par with FYM $\left(\mathrm{M}_{2}\right)$ and castorcake $\left(\mathrm{M}_{3}\right)$.

This might be due to long last residual effect of vermicompost and their complementary effects and also due to addition of organic matter in to the soil through organic manures helped in modifying the soil environment which enhance the availability of nutrients and resulted in improvement of the soil fertility. Hiremath et al., (2016) and Srinivasanarao et al., (2010) reported similar improvements in soil fertility with the use of organic manure. 
Table.1 Residual effect of organic manures and inorganic fertilizer treatment on chickpea growth and yield attributes and soil nutrient status (pooled of two year)

\begin{tabular}{|c|c|c|c|c|c|c|c|c|c|c|c|}
\hline \multirow[t]{2}{*}{ Treatment } & \multirow{2}{*}{$\begin{array}{c}\text { Plant } \\
\text { populatio } \\
\text { n at } 20 \\
\text { DAS }\end{array}$} & \multirow{2}{*}{$\begin{array}{c}\text { Number of } \\
\text { nodules/pl } \\
\text { ant at } 50 \\
\text { DAS }\end{array}$} & \multirow{2}{*}{$\begin{array}{c}\text { Nodules } \\
\text { weight } \\
\text { (mg/plant) }\end{array}$} & \multirow{2}{*}{$\begin{array}{l}\text { Seed } \\
\text { index } \\
(\mathrm{g})\end{array}$} & \multirow{2}{*}{$\begin{array}{c}\text { Seed } \\
\text { yield } \\
\text { (kg/ha) }\end{array}$} & \multirow{2}{*}{$\begin{array}{l}\text { Stover } \\
\text { yield } \\
\text { (kg/ha) }\end{array}$} & \multirow{2}{*}{$\begin{array}{c}\text { Protein } \\
\text { content } \\
(\%)\end{array}$} & \multicolumn{4}{|c|}{ Soil nutrient status after harvest } \\
\hline & & & & & & & & $\mathrm{N}$ & (kg/ha) & $\mathrm{K}_{2} \mathrm{O}$ & $\frac{\mathrm{S}}{(\mathrm{mg} / \mathrm{kg})}$ \\
\hline \multicolumn{12}{|c|}{ Organic manure $(\mathbf{M})$} \\
\hline $\mathbf{M}_{1}$ & 300.2 & 13.8 & 194.1 & 23.2 & 937 & 1425 & 19.5 & 224.4 & 52.2 & 224.4 & 15.2 \\
\hline $\mathbf{M}_{2}$ & 310.9 & 21.8 & 225.2 & 26.1 & 1199 & 1794 & 21.3 & 287.6 & 60.1 & 290.9 & 18.0 \\
\hline $\mathbf{M}_{3}$ & 305.8 & 18.7 & 208.2 & 25.5 & 1126 & 1686 & 20.7 & 274.5 & 63.4 & 239.4 & 17.1 \\
\hline $\mathbf{M}_{4}$ & 307.7 & 21.0 & 216.4 & 25.9 & 1162 & 1888 & 20.9 & 291.5 & 63.8 & 252.5 & 18.0 \\
\hline S.Em. \pm & 2.96 & 0.35 & 3.65 & 0.45 & 26.0 & 40.6 & 0.3 & 8.08 & 0.58 & 11.90 & 0.32 \\
\hline C. D. at $5 \%$ & NS & 1.0 & 10.3 & 1.3 & 73 & 114 & 0.9 & 36.4 & 1.6 & NS & 0.9 \\
\hline \multicolumn{12}{|c|}{ Inorganic fertilizer $(\mathbf{F})$} \\
\hline $\mathbf{F}_{1}$ & 303.4 & 18.5 & 208.7 & 24.9 & 1059 & 1627 & 20.4 & 255.8 & 55.6 & 250.9 & 16.8 \\
\hline $\mathbf{F}_{2}$ & 308.9 & 19.1 & 213.2 & 25.5 & 1154 & 1770 & 20.8 & 283.2 & 64.1 & 252.7 & 17.4 \\
\hline S.Em. \pm & 2.09 & 0.25 & 2.58 & 0.32 & 18.4 & 28.7 & 0.2 & 3.35 & 1.05 & 2.77 & 0.23 \\
\hline C. D. at $5 \%$ & NS & NS & NS & NS & 52 & 80.6 & NS & 9.4 & $\mathrm{NS}$ & NS & NS \\
\hline \multicolumn{12}{|l|}{ Sulphur (S) } \\
\hline$S_{1}$ & 306.4 & 18.8 & 205.8 & 25.1 & 1084 & 1690 & 20.5 & 266.1 & 59.5 & 250.7 & 16.8 \\
\hline $\mathbf{S}_{2}$ & 305.9 & 18.8 & 216.2 & 25.3 & 1129 & 1706 & 20.7 & 273.0 & 60.2 & 252.8 & 17.4 \\
\hline S.Em. \pm & 2.09 & 0.25 & 2.58 & 0.32 & 18.4 & 28.7 & 0.2 & 3.35 & 0.41 & 2.77 & 0.23 \\
\hline C. D. at $5 \%$ & NS & NS & 7.2 & NS & NS & NS & NS & NS & NS & NS & NS \\
\hline Interaction & - & - & - & - & - & - & - & - & - & - & - \\
\hline C. V. \% & 5.5 & 10.5 & 9.8 & 10.1 & 13.3 & 13.5 & 9.0 & 10.0 & 5.5 & 8.8 & 10.6 \\
\hline
\end{tabular}




\section{Effect of inorganic fertilizer}

Residual effect of $100 \% \operatorname{RDF}\left(\mathrm{F}_{2}\right)$ was recorded non-significant on plant population at 20 DAS, number of nodules/plant, weight of nodules/plant, seed index, protein content and soil available phosphorus, potash and sulphur over $75 \%$ RDF $\left(F_{1}\right)$ (Table 1$)$. The significantly highest value of seed yield (1154 $\mathrm{kg} / \mathrm{ha})$ and stover yield $(1770 \mathrm{~kg} / \mathrm{ha})$ of chickpea were recorded with the residual effect of treatment $\mathrm{F}_{2}(100 \% \mathrm{RDF})$ which was at par with treatment $\mathrm{F}_{1}(75 \% \mathrm{RDF})$.

The increased in seed and stover yield of chickpea due to residual effect of $100 \%$ RDF over $75 \%$ RDF was to the tune of 9.0 and 8.8 per cent, respectively.This was largely attributed to better growth of plant, which resulted adequate supply of photosynthates for development of sink. Thus, the overall better growth performance and higher values of the yield attributes reflected into higher seed and stover yields. Similar findings were reported by Kumar et al., (2015) and Hiremath et al., (2016).

\section{Effect of sulphur}

Data presented in Table 1 indicated that residual effect of sulphur was found nonsignificant on chickpea growth and yield attributes, yield as well as after harvest soil nutrient status of soil except nodule weight/plant (Table 1).

Sulphur applied to maize crop and its residual effect on chickpea crop was found significant on nodule weight/plant. Treatment $S_{2}$ gave 5.1 per cent higher nodule weight/plant than treatment $S_{1}$. This increased might be due to involvement of sulphur in synthesis of sulphur containing amino acid and also chickpea seed treated with rhizobium culture which might helped in increasing the availability of sulphur. The findings corroborate the observations of Srinivasanarao et al., (2010).

On the basis of experimental results, it could be concluded that residual effect of recommended dose of fertilizer $(120-60-00 \mathrm{~kg}$ NPK/ ha) along with FYM @ 10 t/ha gave higher seed and stover yields of chickpea in maize - chickpea cropping sequence and also maintain soil health.

\section{Acknowledgement}

Authors are very much thankful to the Director of Research and Dean P.G. Studies, AAU, Anand; Principal and Dean, B.A.College of Agriculture and Professor and Head, Department of Agronomy and my guide for valuable guidance and support to conduct the my research program and obtain its significant findings.

\section{References}

Cochran, W. G. and Cox, G. M. Experimental designs, John Willey and Sons. Inc., New York, 1957; 546-568.

De Datta and Hundal Improving nitrogen fertilizer efficiency in low land rice in tropical Asia. In: Nitrogen economy of flooded rice soils. Martinus Nijhoff Pub. Baston. pp. 1984; 171-186.

Gawai, P. P. and Pawar, V. S. Integrated nutrient management in sorghumchickpea cropping sequence under irrigated conditions. Indian J. Agron., 2006; 51(1): 17-20.

Hiremath S. M., Mohankumar R. and Gaddi A. Influence of balanced nutrition on productivity, economics and nutrient uptake of hybrid maize- chickpea cropping sequence under irrigated ecosystem. Indian J. Agron., 2016; 61 (3): 292-296.

Inoko, A. Compost as sources of plant nutrients. In: Organic matter and rice. 
IRRI, Los Banos, Philippines. Pp. 1984; $137-145$.

Kumar M. R. and Hiremath S. M. Residual effect of maize hybrids, plant population and fertility levels on performance of chickpea in maizechickpea cropping sequence. Karnataka J. Agric. Sci., 2015; 28 (4): 482-485.

Shahid I., Christian T., Khan H. Z., Javeed H.M.R., Arif M. and Shehzad M. Maximizing maize quality, productivity and profitability through a combined use of compost and nitrogen fertilizer in a semi-arid environment in Pakistan. Nutr Cycl Agroecosyst., 2017; 107: 197-
213.

Sindhi S. J., Thanki J. D., Mansuri R. N. and Desai L. J. Residual effect of integrated nutrient management in rabi maize on growth and yield of summer greengram under maize - greengram cropping sequence. Int. J. Agril. Sci., 2016; 52(8): 2443-2445.

Srinivasanarao, Massod, Ali, Venkateswarlu, S., Rupa, T. R., Singh, K. K., Kundu, S. and Prasad, J. V. N. S. Direct and residual effect of integrated sulphur fertilization in maize- chickpea cropping system on Typicustochrept. Indian J. Agron., 2010; 55 (4): 259-263.

\section{How to cite this article:}

Lakum, Y. C., H. K. Patel, G. G. Patel, P. D. Patel and Patel, D. K. 2020. Residual Effect of Manure and Fertilizer on Growth, Yield of Chickpea and Soil Nutrient Status under MaizeChickpea Cropping System. Int.J.Curr.Microbiol.App.Sci. 9(04): 2940-2945.

doi: https://doi.org/10.20546/ijcmas.2020.904.344 